Dana Walrath

\title{
Transmuting Transgenerational Trauma: Dementia, Storytelling and Healing
}

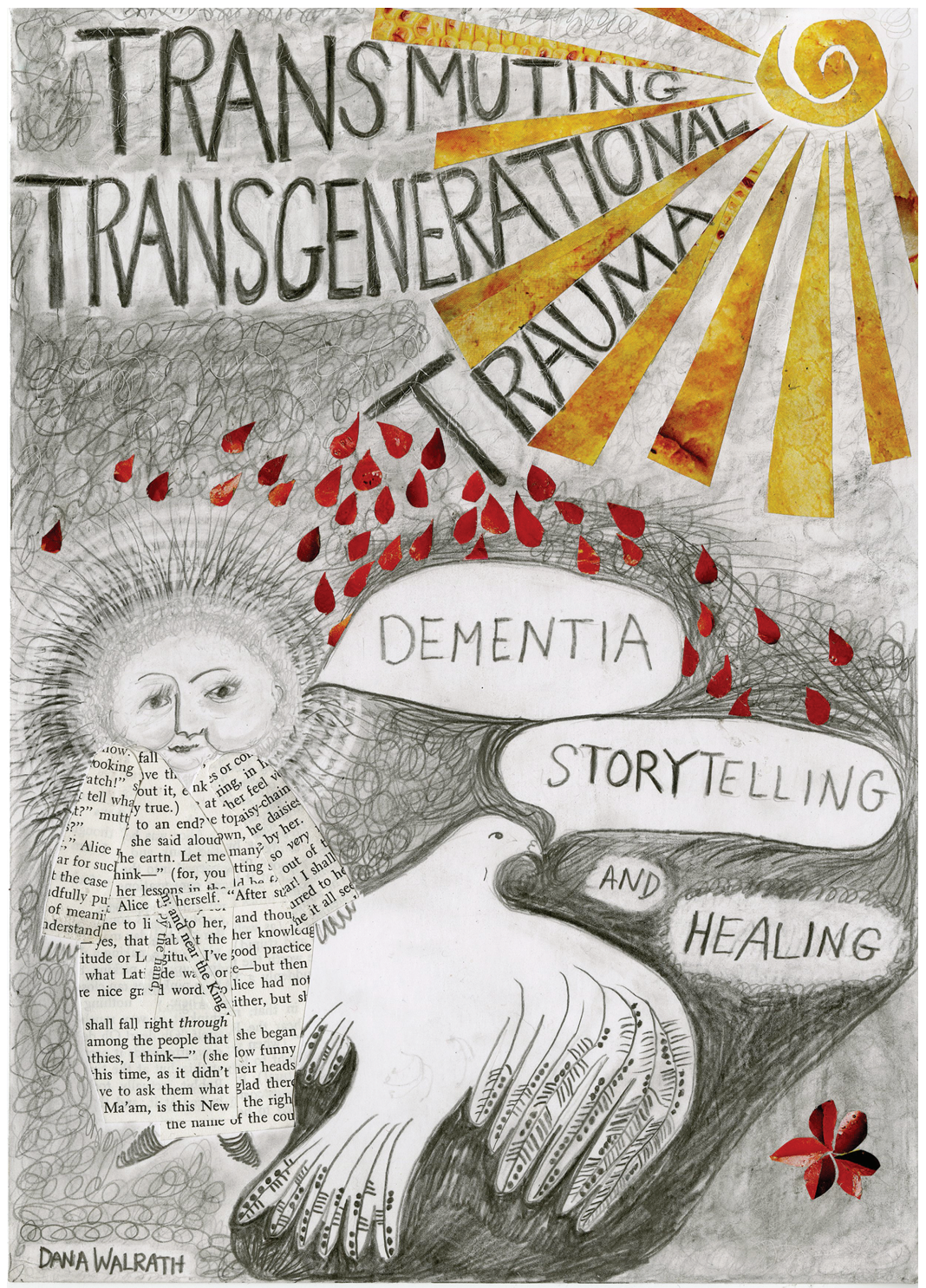

ə) Open Access. (๑) 2022 Dana Walrath, published by De Gruyter. (G) BY-NC-ND This work is licensed under the Creative Commons Attribution-NonCommercial-NoDerivatives 4.0 International License. 

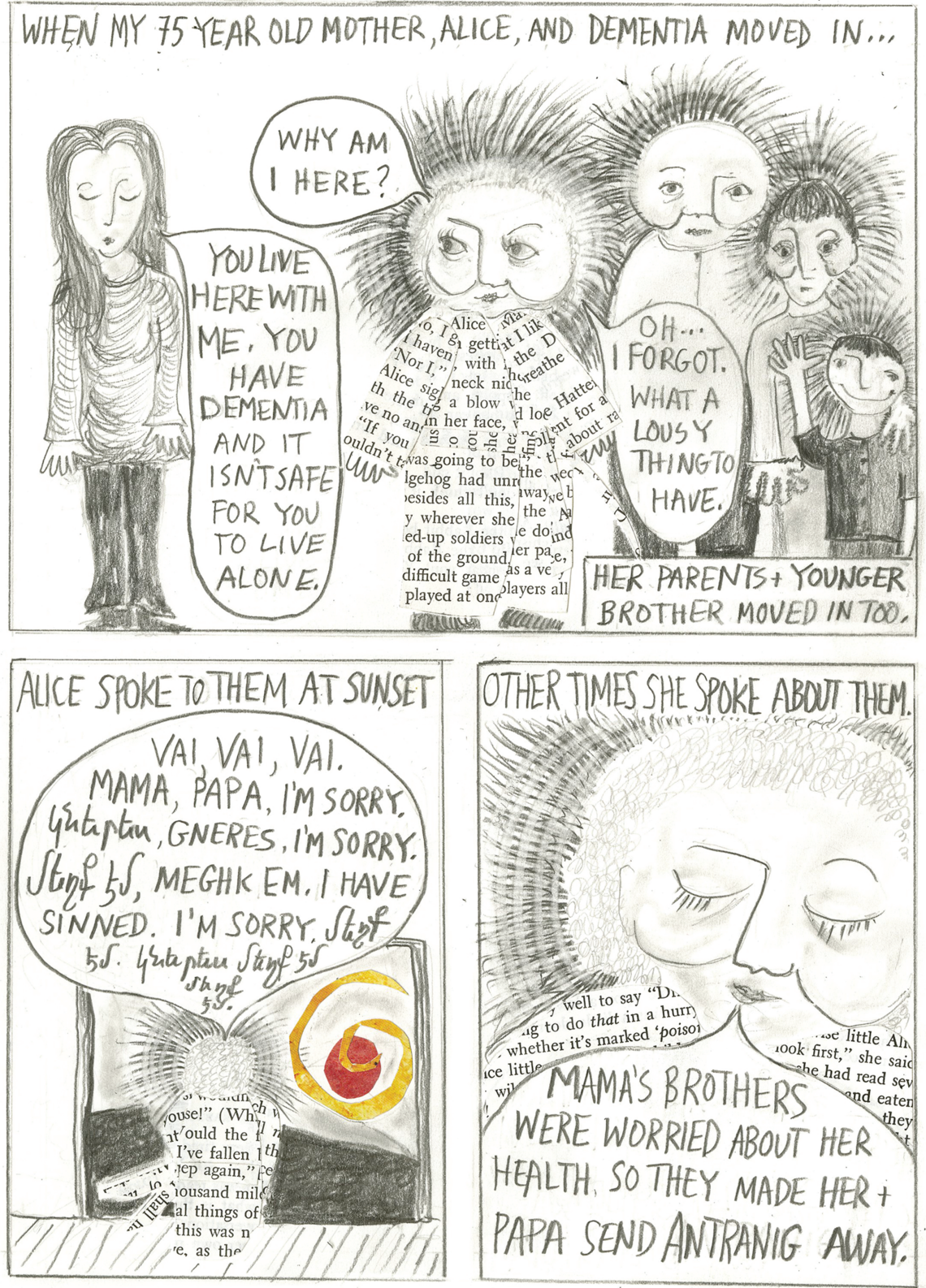

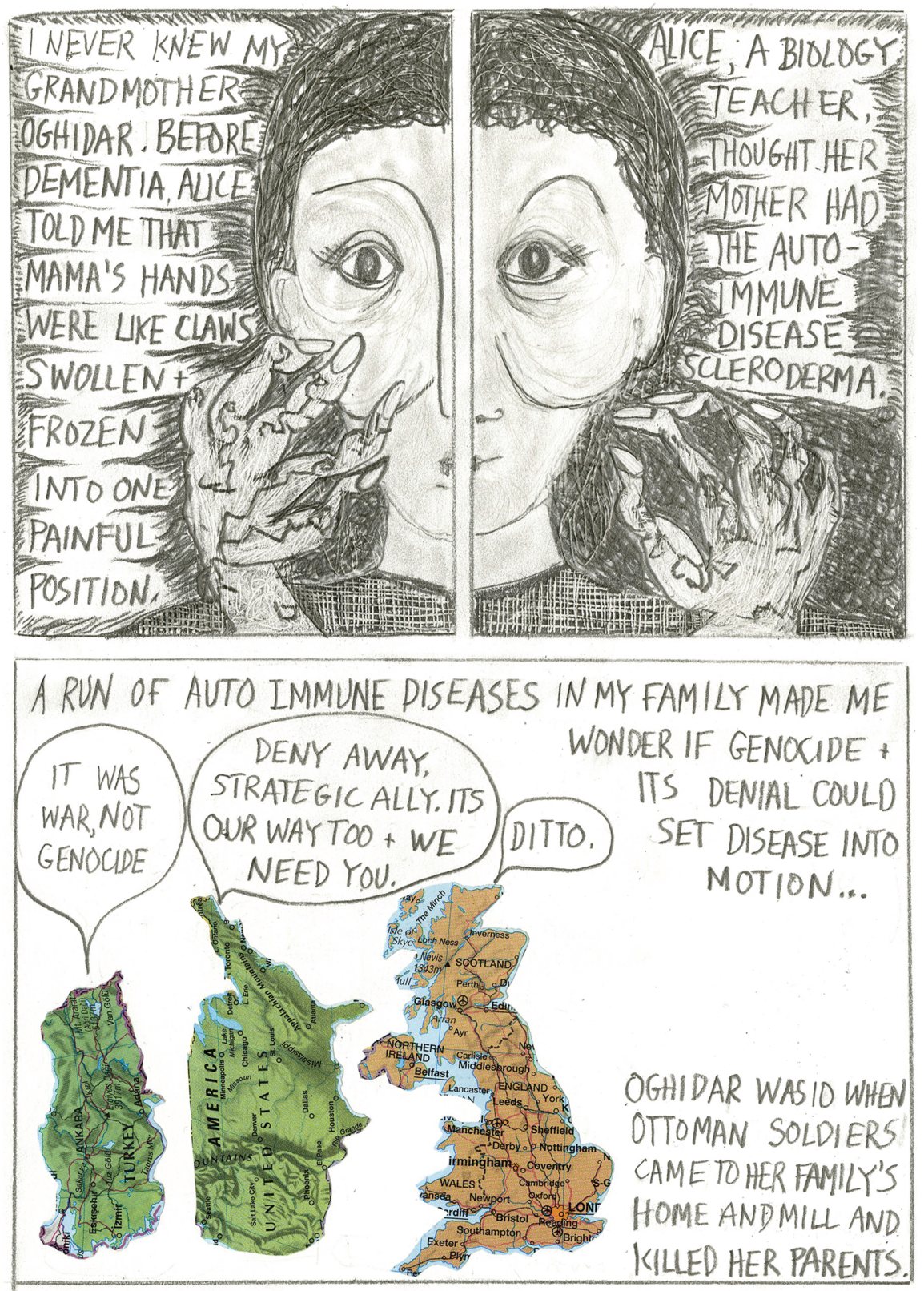

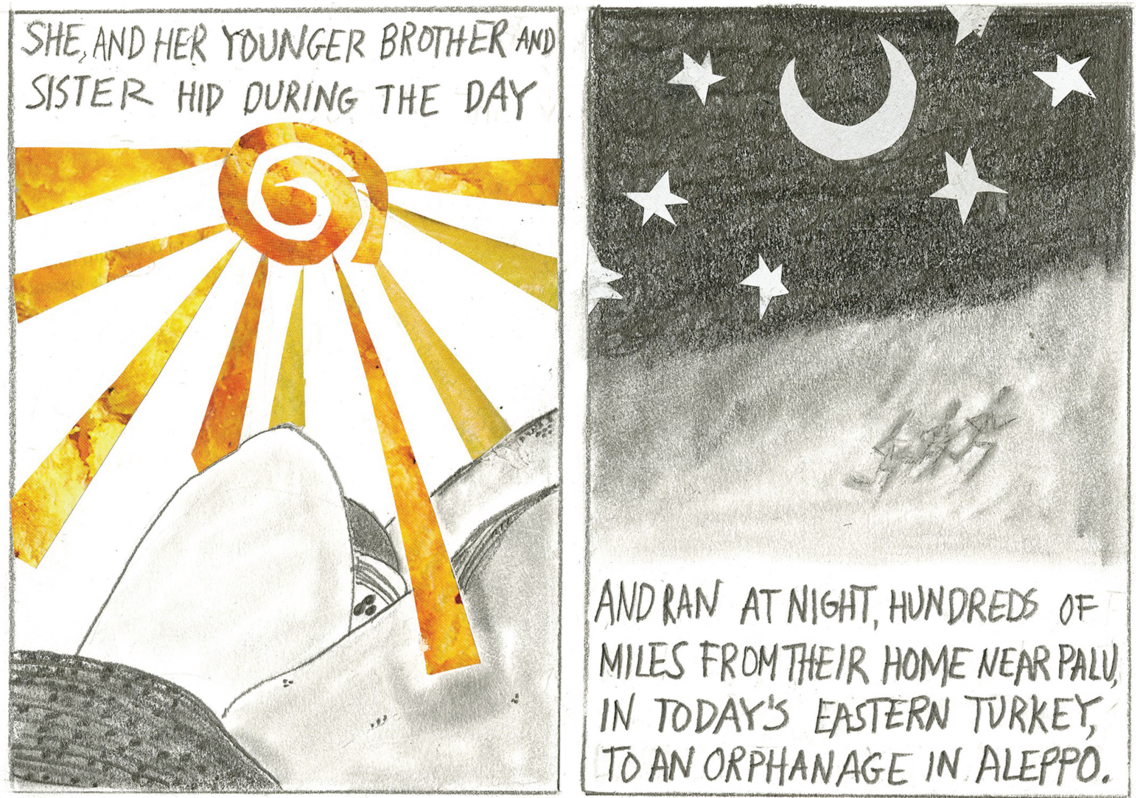

MY GRANDFATHER, YEGHISHE, AMARRIED MAN WITH TWO SONS AND SEVEN SISTERS LIVED HIS OWN BLDODY HISTORY THROUGH THE GENOCIDE WHICH, LKE MY GRANDMOIHER'S, WAS REDUCEDTD 1 STARK SENTENCE.

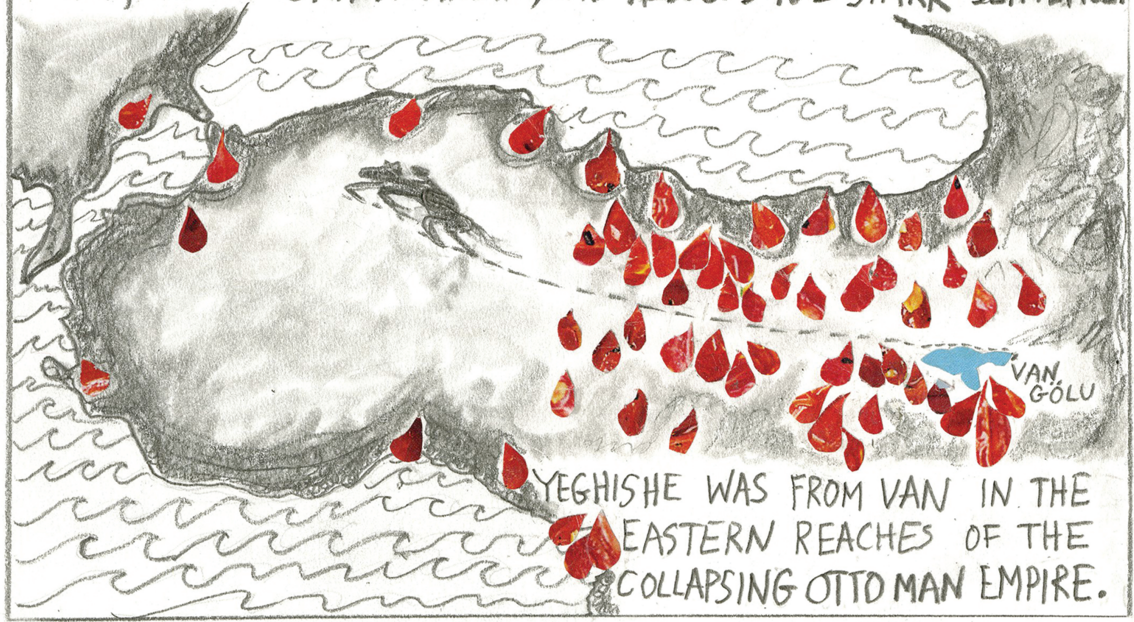



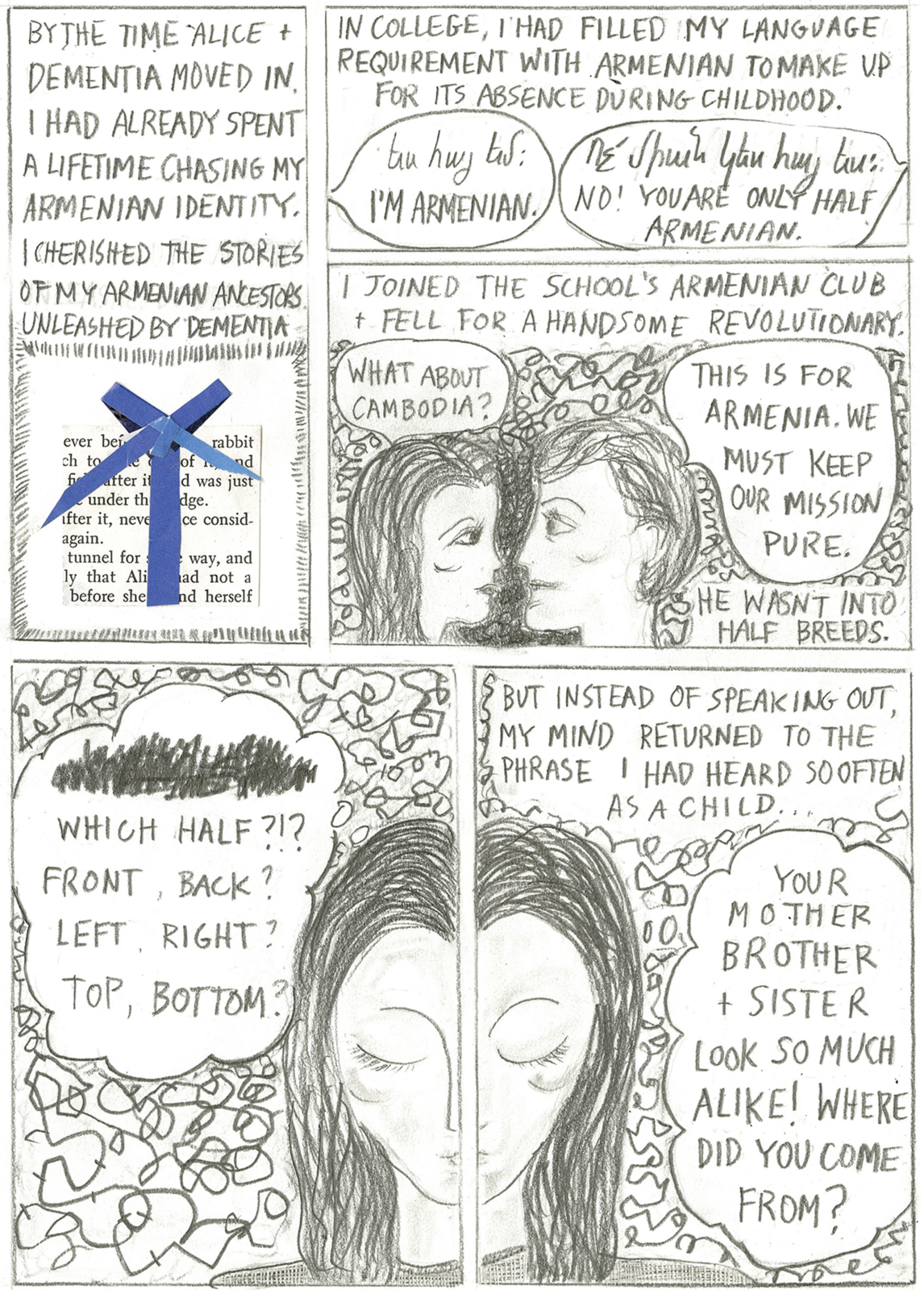

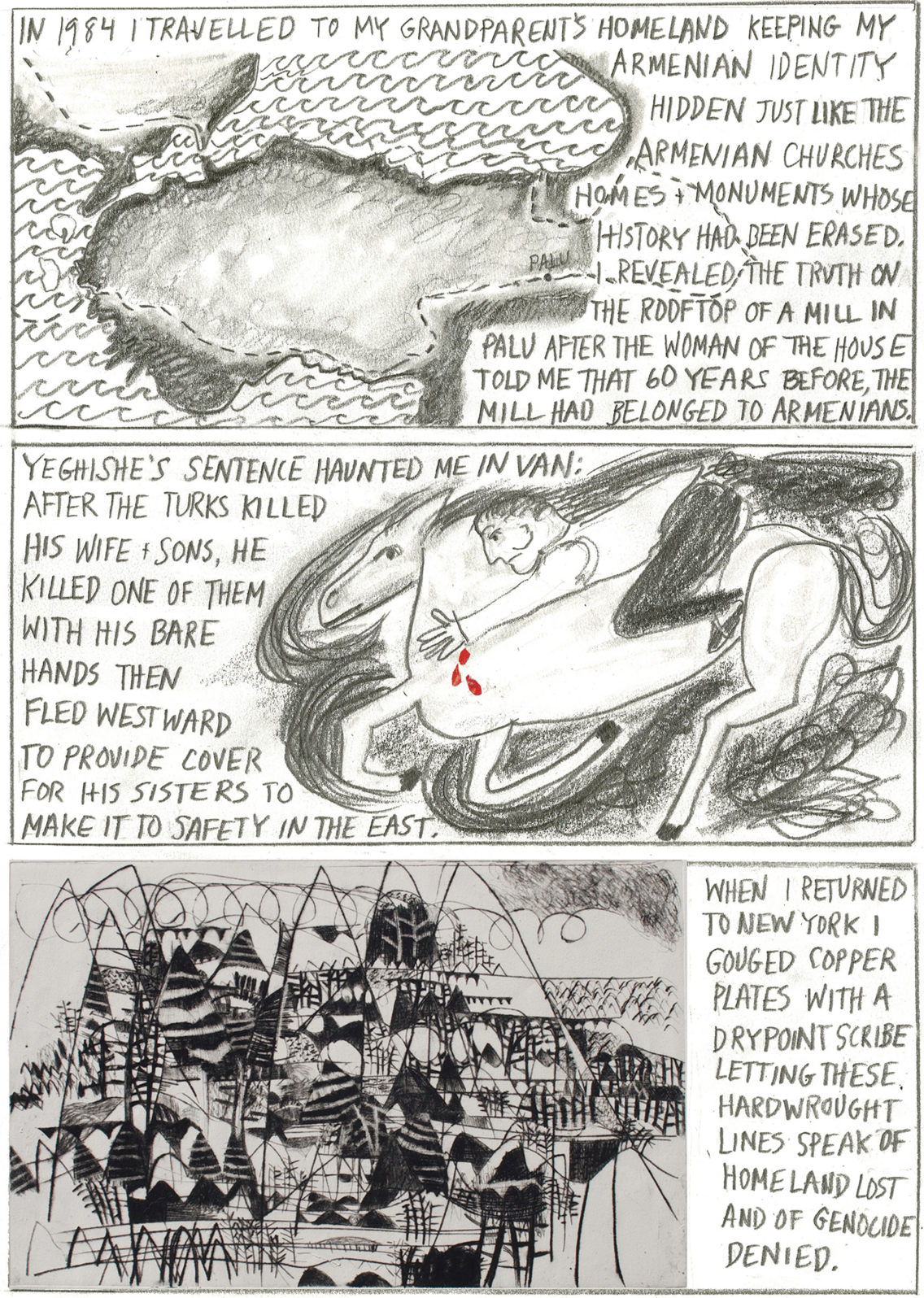
WHAT ELSE: DID I KNOW BEFORE DEMENTIA?

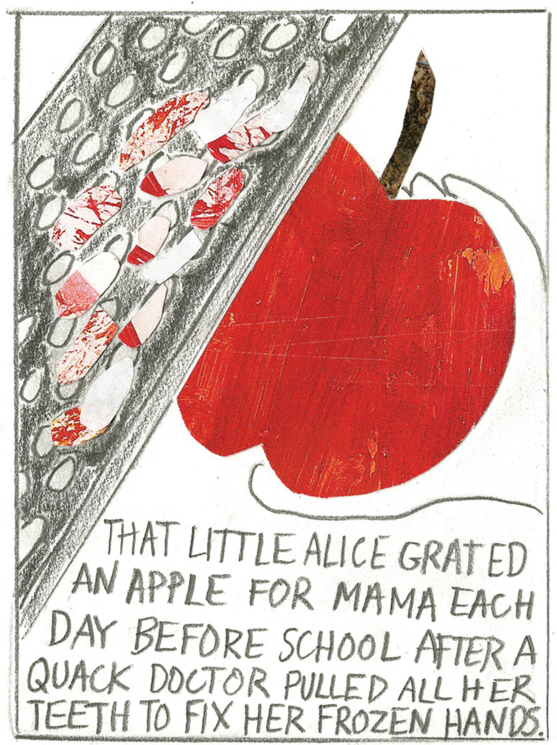

THAT SADNESS, SHAME, VOLATILITY LURKED BELOW HER GLAMOUR AUTHORITY + DETERMINATION.

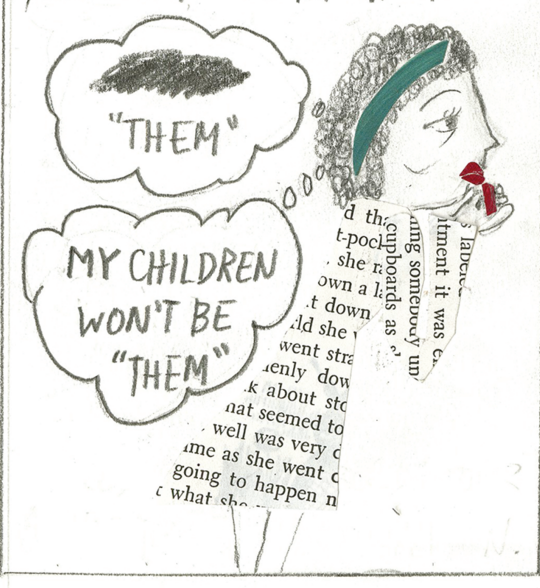

THAT ALILE REVERED MDS.
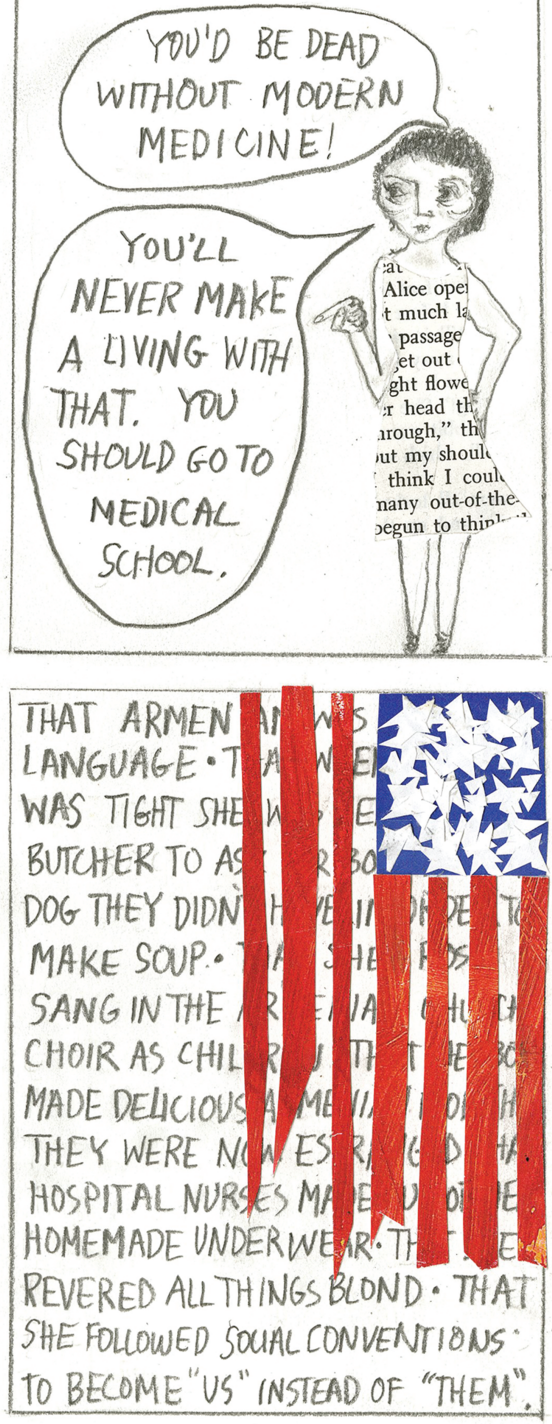

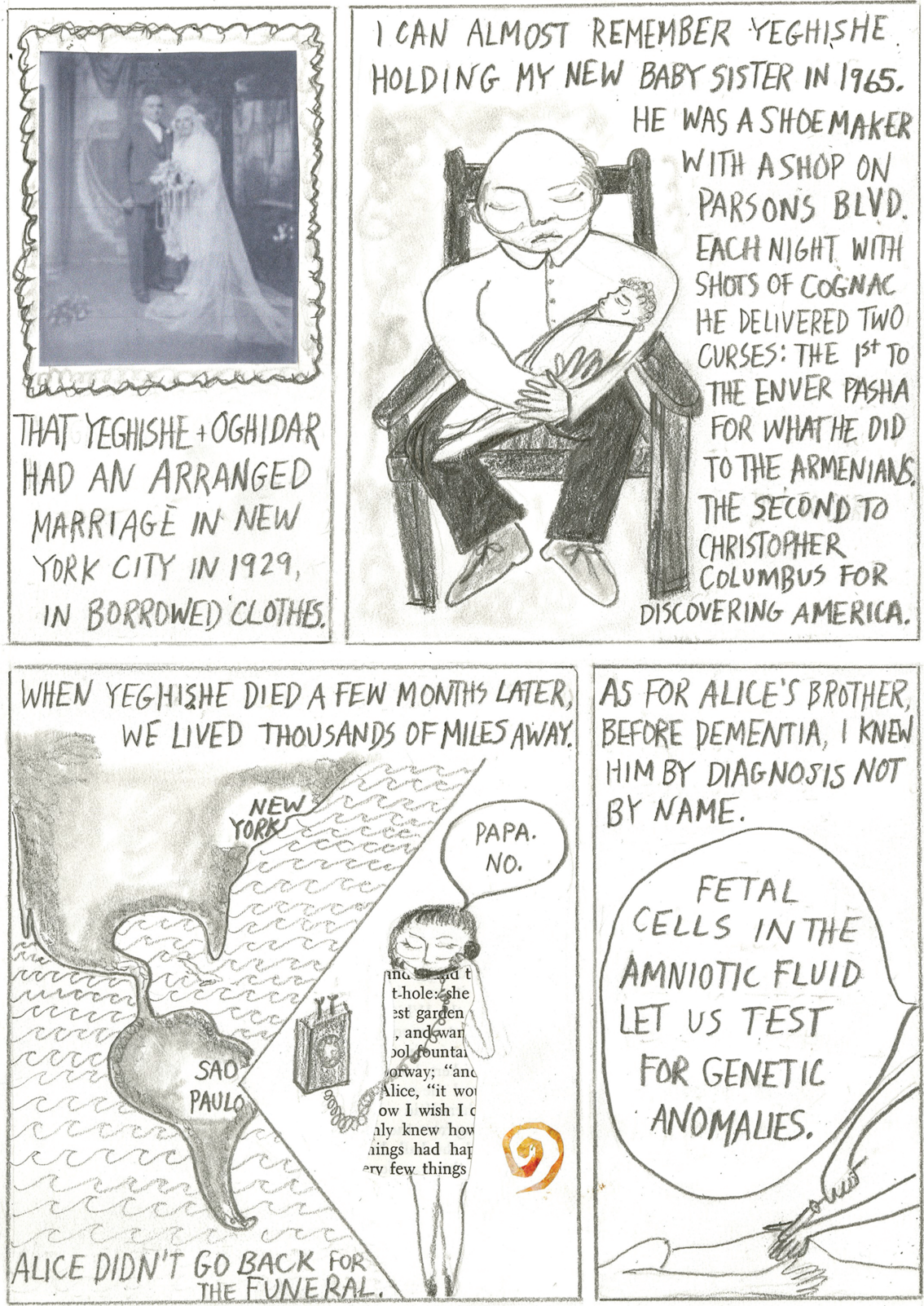

AS FOR ALICE'S BROTHER, BEFORE DEMENTIA, I KNEN HIM BY DIAGNOSIS NOT BY NAME.

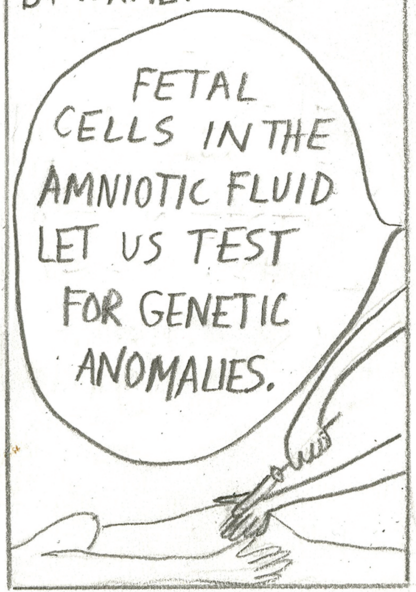




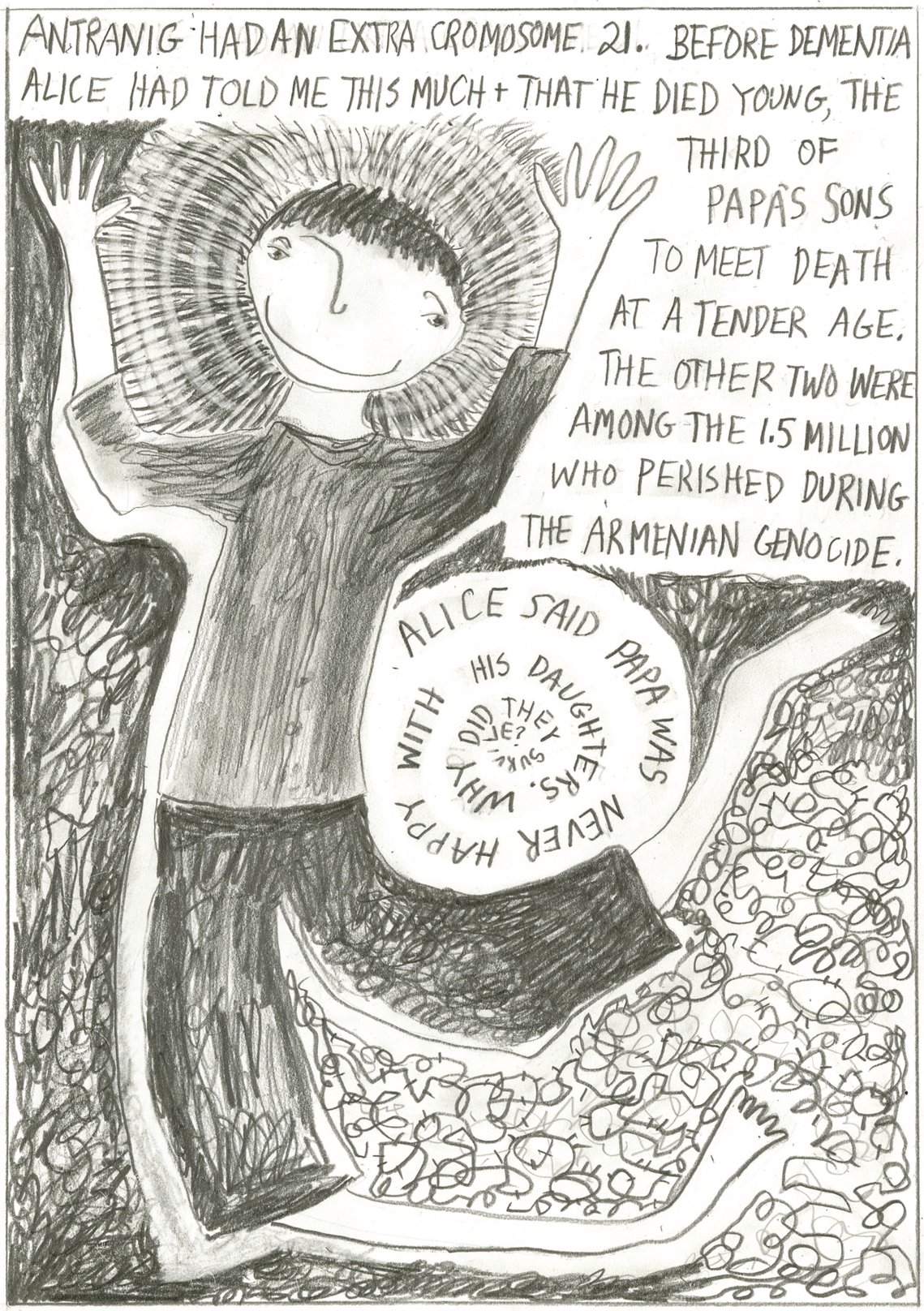



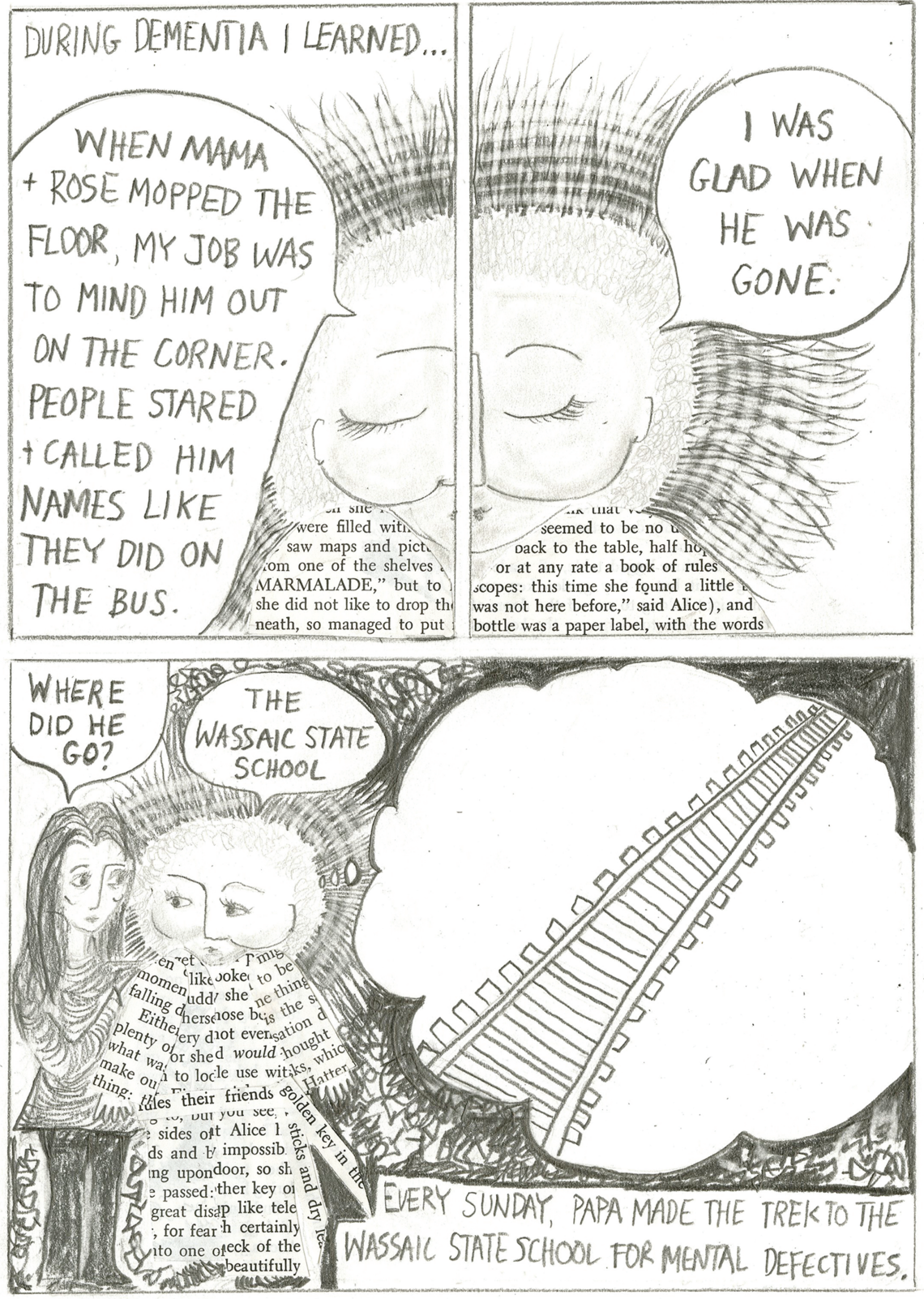

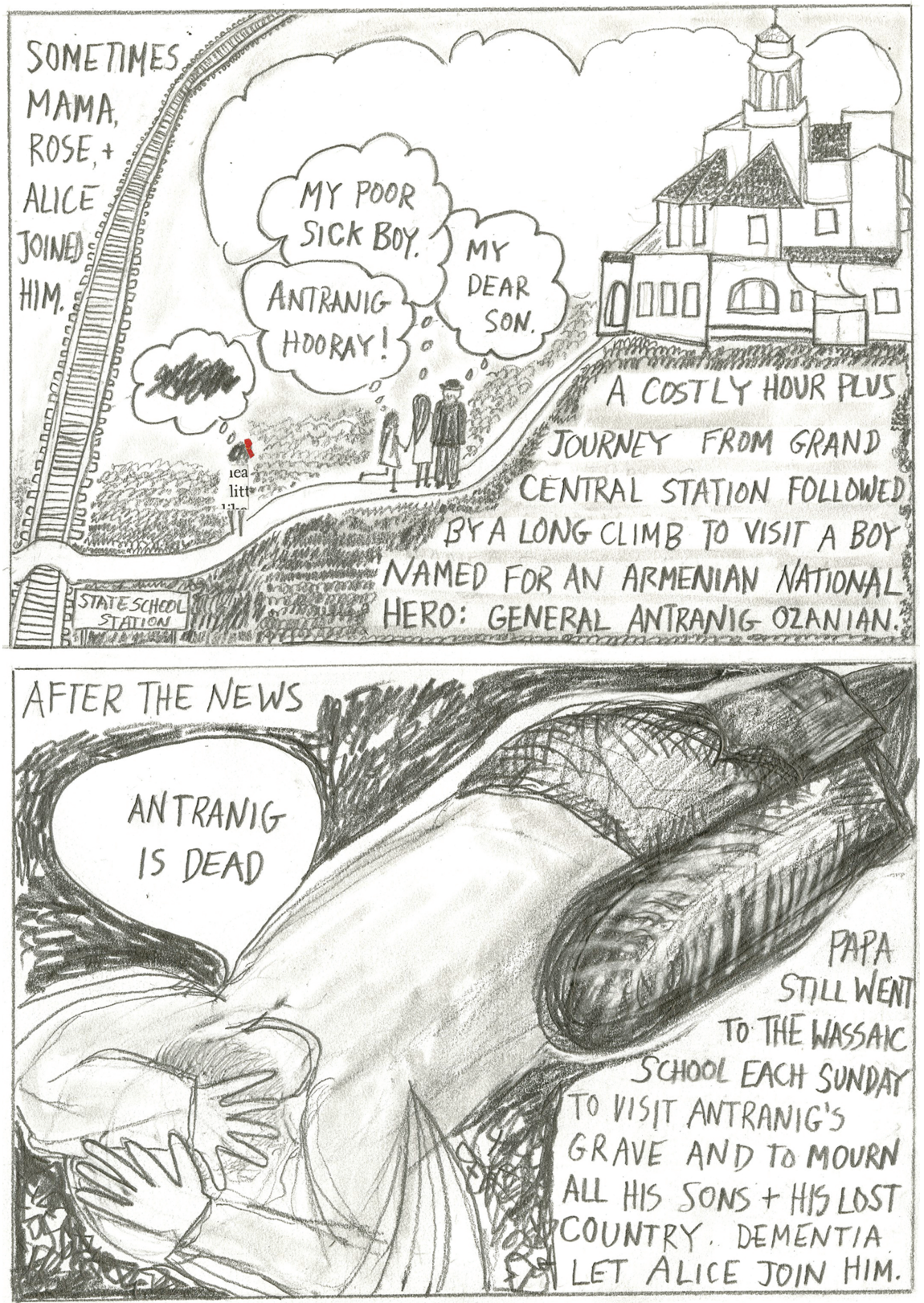

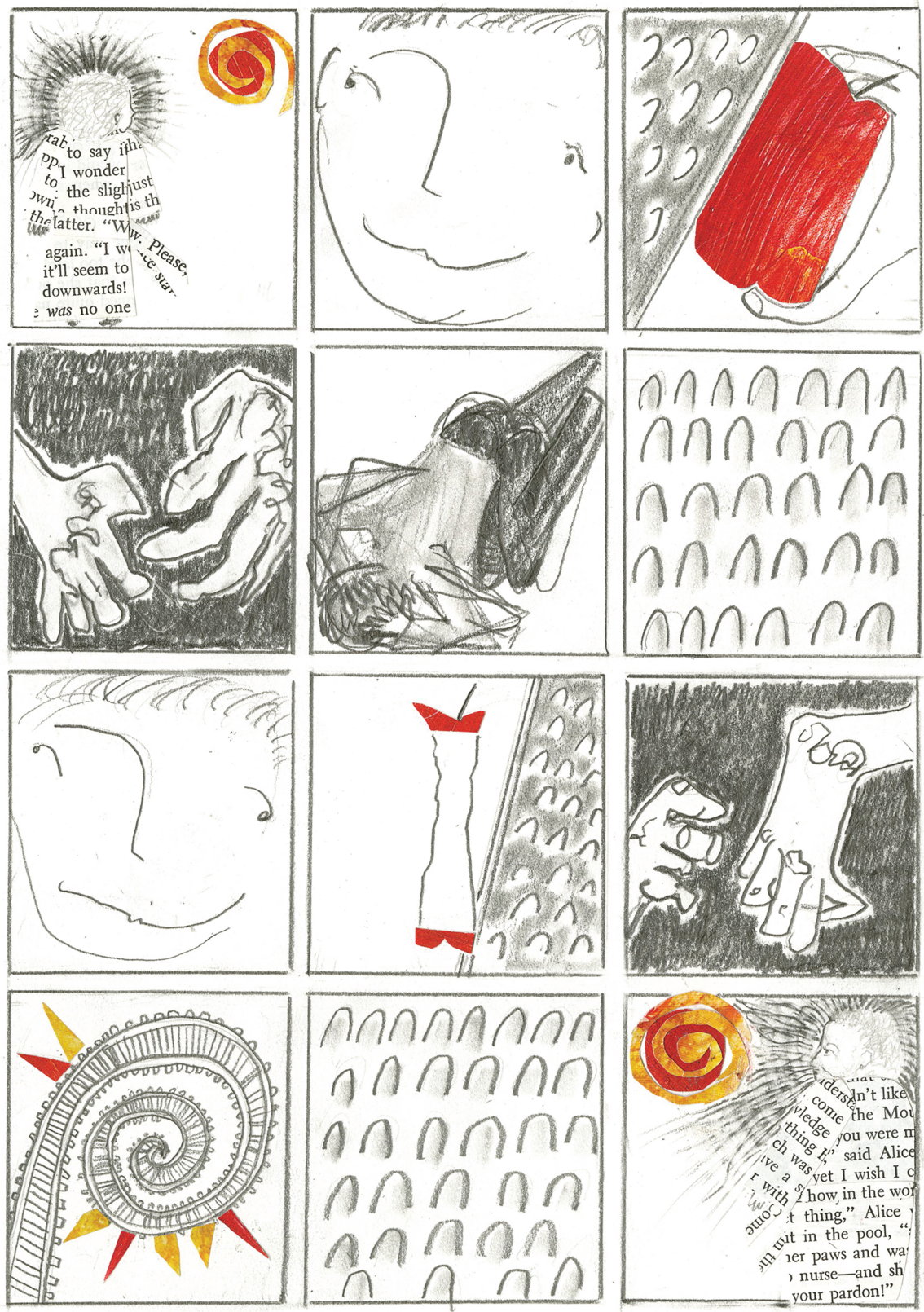

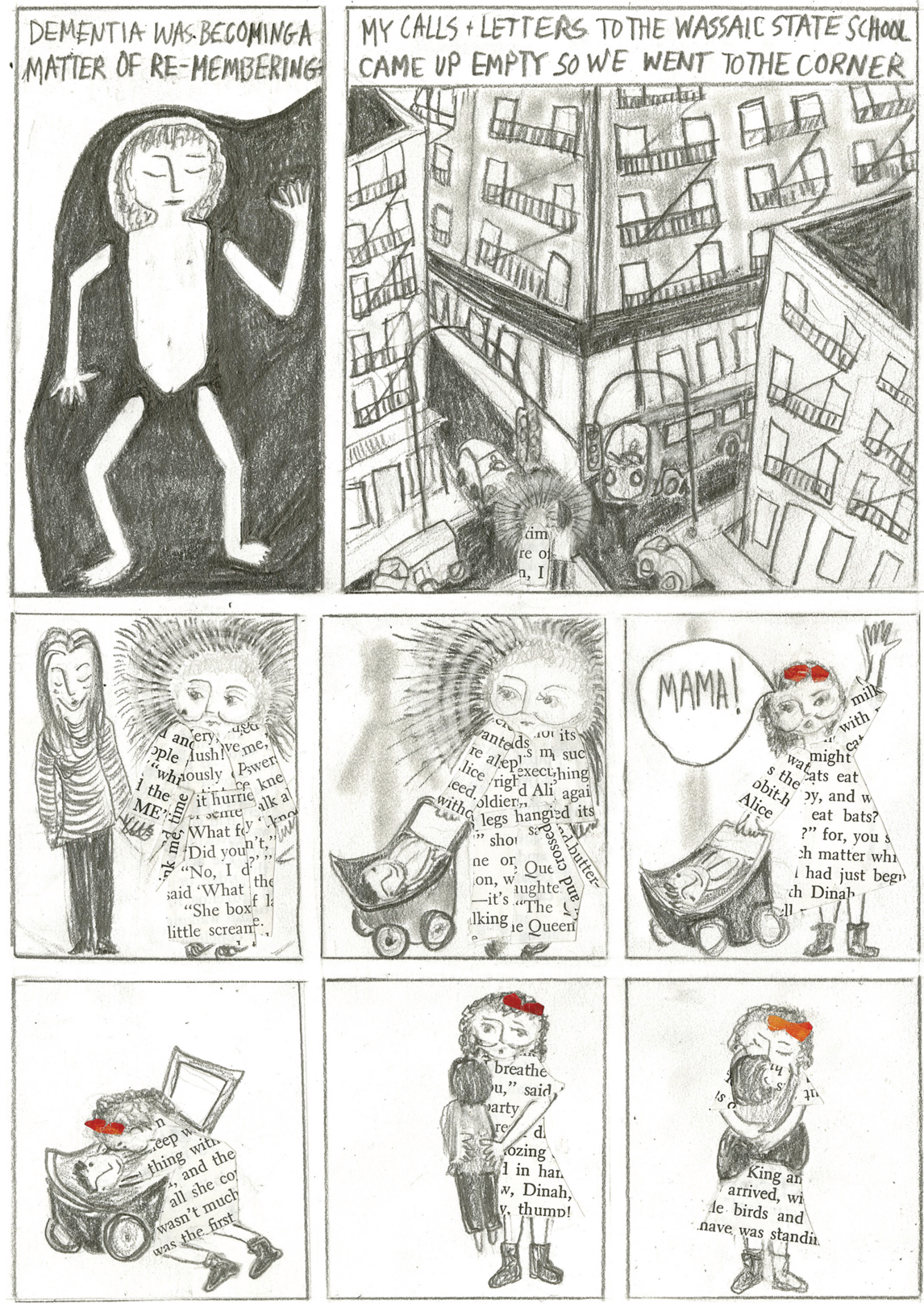


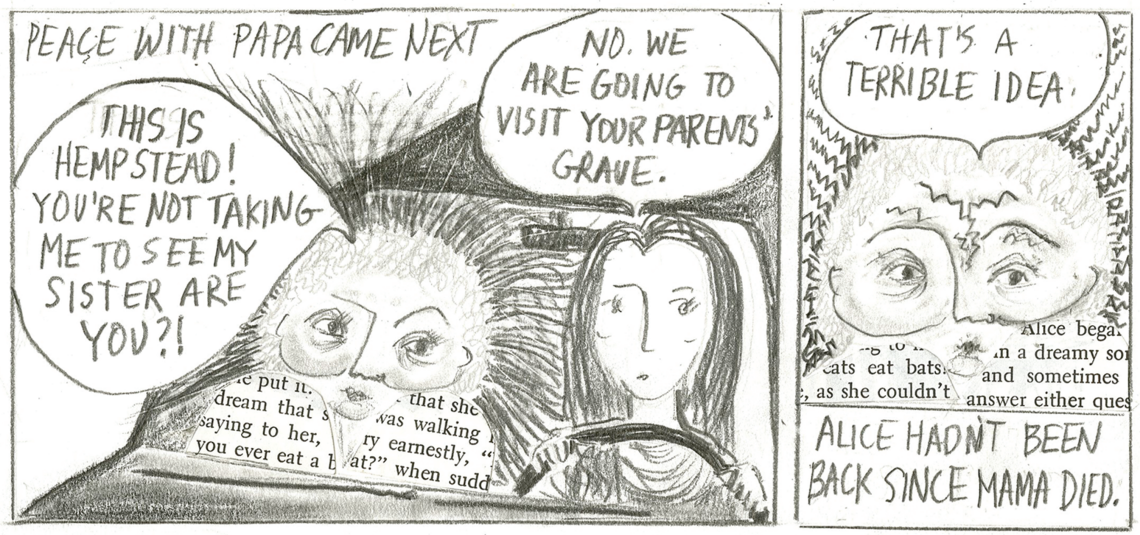

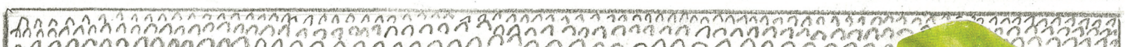

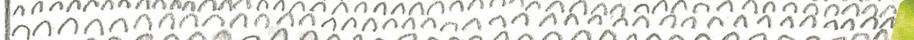

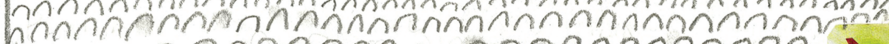

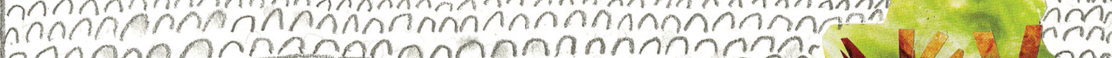
hnh

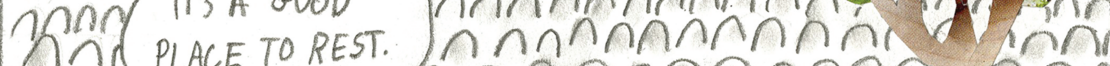

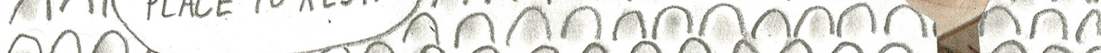

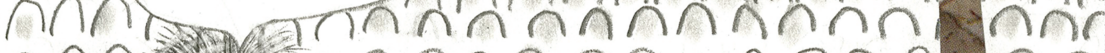

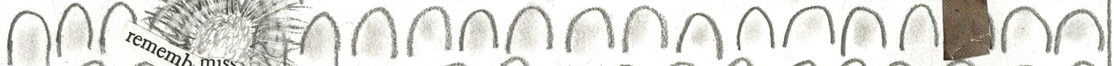

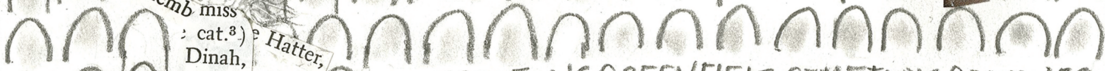

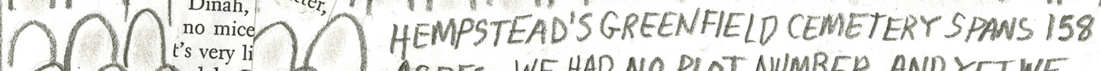
4 ACRES. WE HAD NO PLOT NUMBER AND YET WE

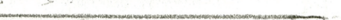
FOUND THEIR GRAVE IN UNDER 20 MINUTES:

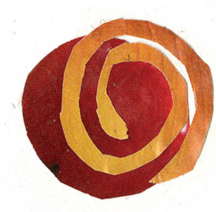

DID THE ANCESTORS HELP US FIND THEM? ALL I KNOW IS FROM THAT DAY FORWARD, ALICE NO LONGER MET THEMWNH AGTTATIONAT SUNSET.
TIHE MONTHS THAT FOLLOWED WERE RICH WITH RE-MEMBERING. I LEARNED AS MUCH ABOUT ALICE AS PAPA WHEN SHE REVEALED THAT HE HAD WORKED THE FORD MOTOR LINE IN DETROTT BEFORE HE 100 CAME TO NEW YORK

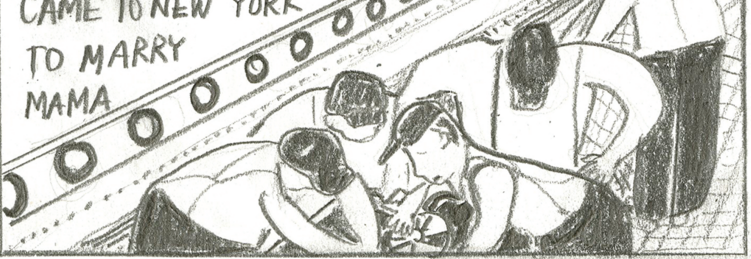



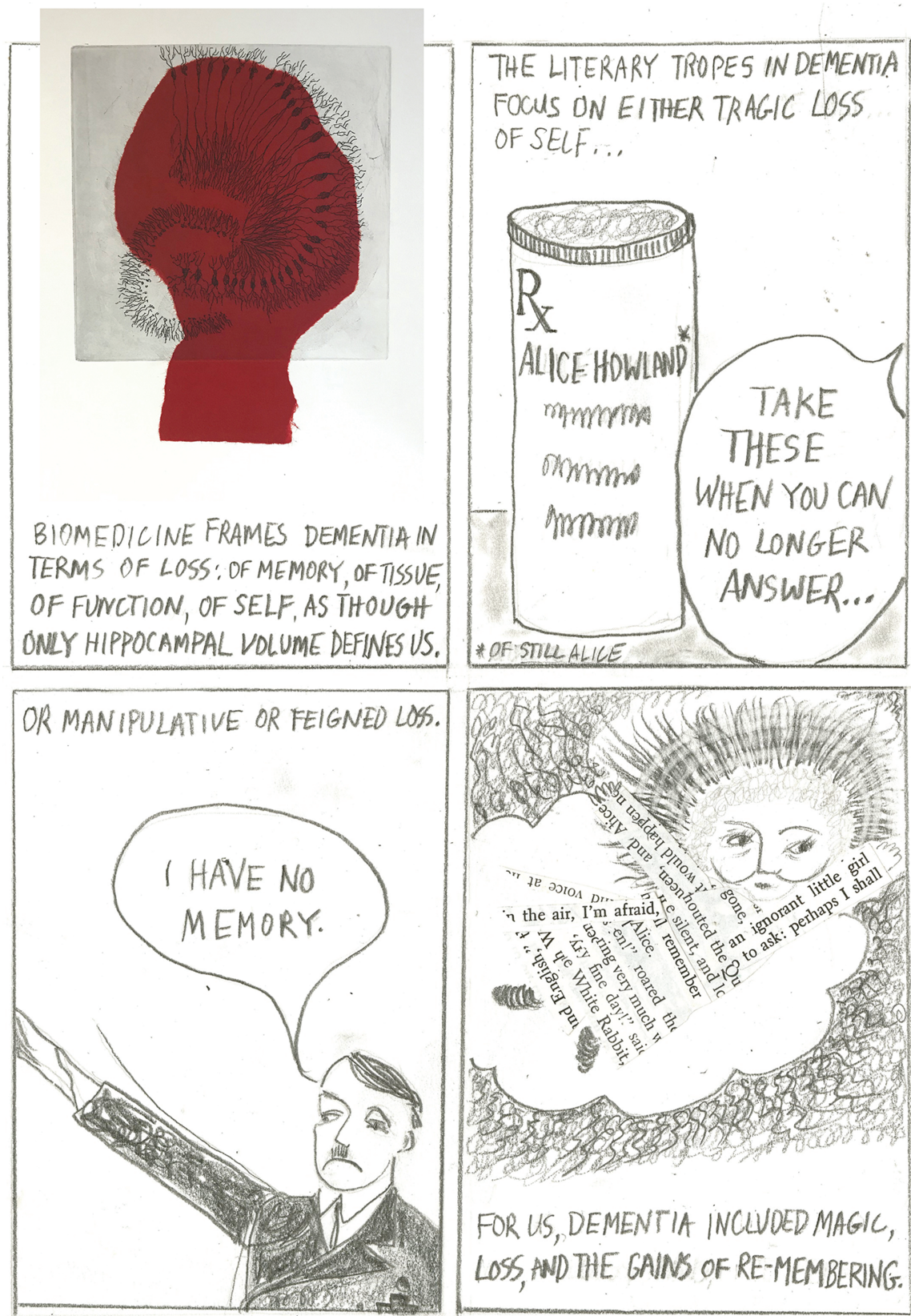


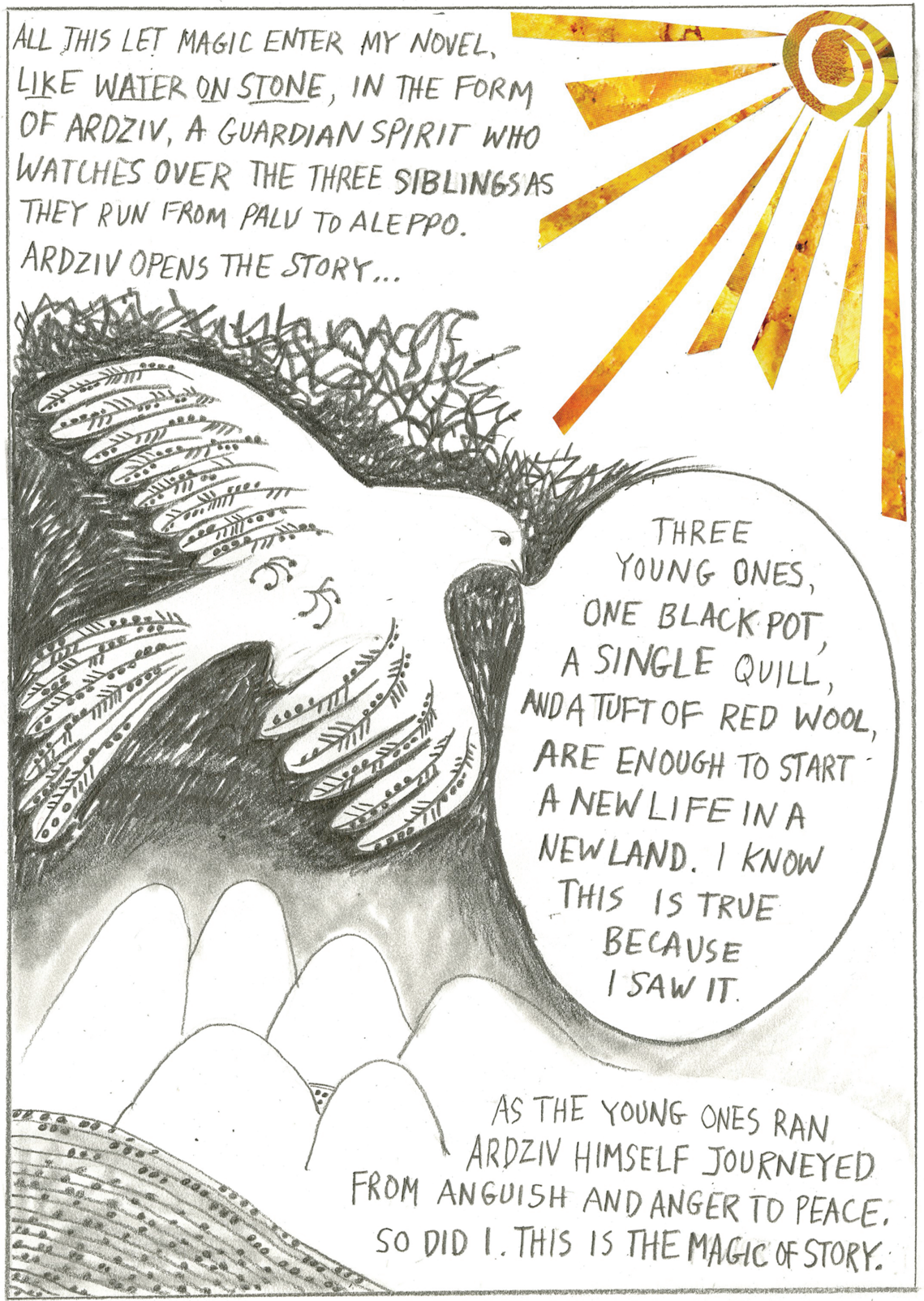



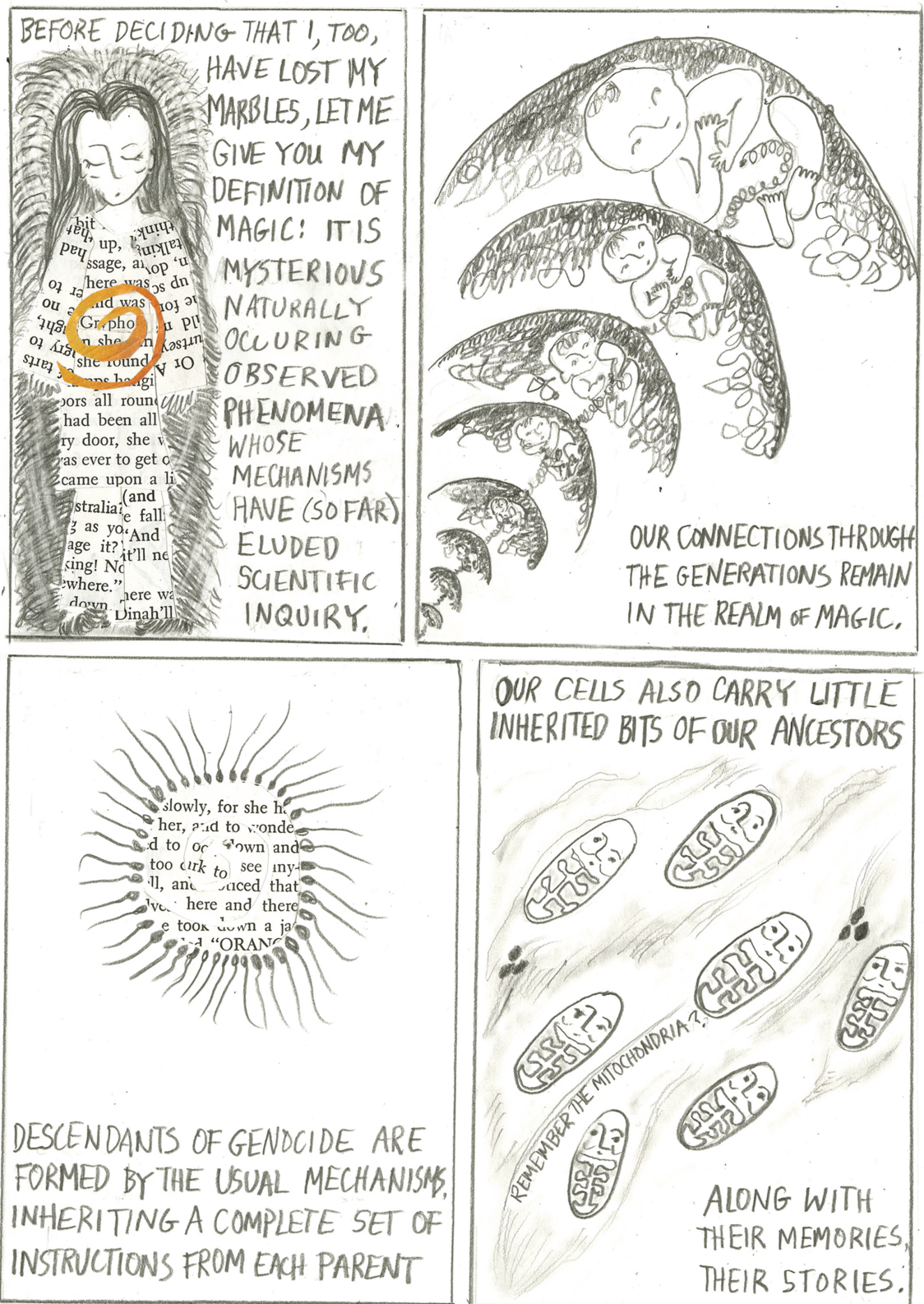

OUR CELLS ALSO CARRY LITTLE INHERITED BITS OF OUR ANCESTORS

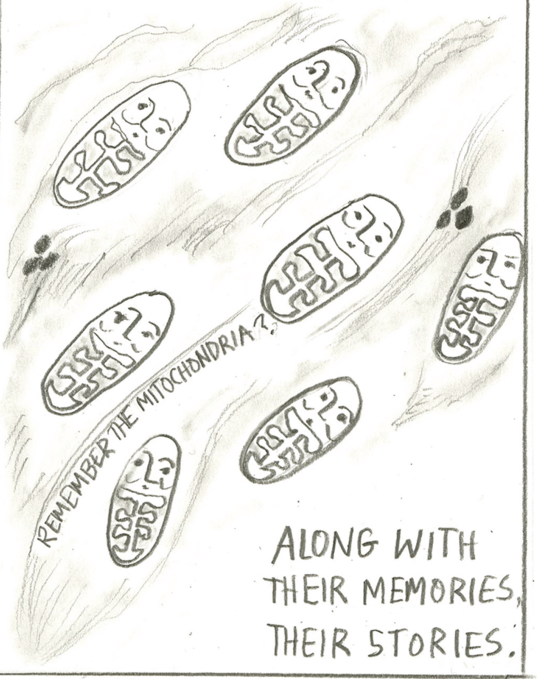



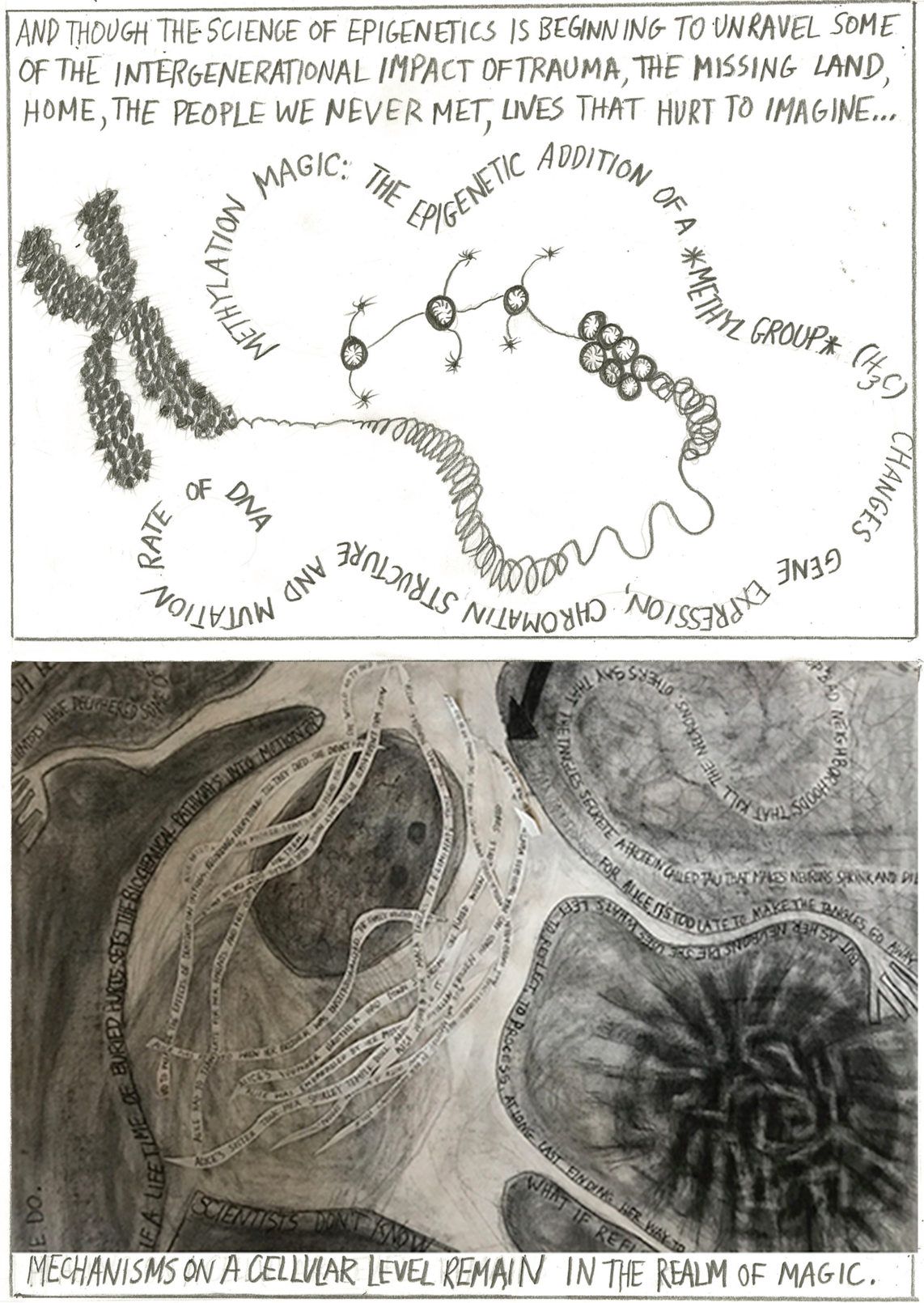

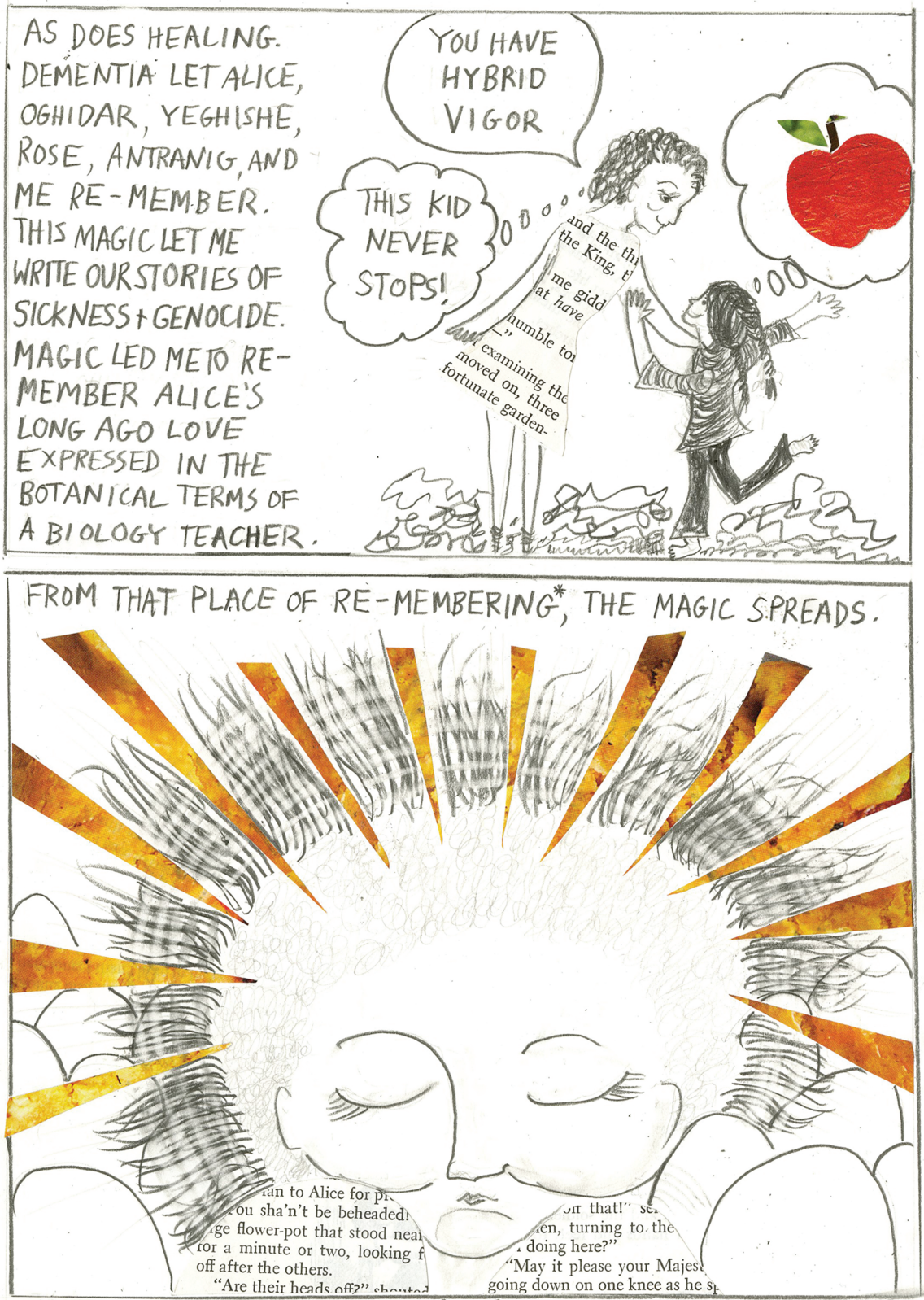

* GRATITUDE TO DURKHANAI AYUBI FORTHE

CONCEPT OF RE-MEMBERING AFTER TRAUMA. 
